\title{
Ethanol from Softwood Biomass: Review Article
}

\author{
Divya Tandon ${ }^{1 *}$ and Nivedita Sharma ${ }^{2}$ \\ ${ }^{1}$ Department of Microbiology, SILB, Solan, \\ ${ }^{2}$ Microbiology Research Laboratory, Department of Basic Sciences, Dr. Y. S. Parmar \\ University of Horticulture and Forestry, Nauni, Solan (HP) - 173230 India \\ *Corresponding author
}

\begin{tabular}{|l|}
\hline Key w or d s \\
$\begin{array}{l}\text { Ethanol, } \\
\text { Softwood biomass, } \\
\text { Depolymerising } \\
\text { enzymes }\end{array}$ \\
\hline Article Info \\
\hline $\begin{array}{l}\text { Accepted: } \\
\text { 20 January } 2019 \\
\text { Available Online: } \\
\text { 10 February } 2019\end{array}$ \\
\hline
\end{tabular}

A B S T R A C T

Pine waste generated as needle biomass is a serious threat to our environment in Himachal Pradesh in terms of recalcitrance of soil as well as forest fire. According to forest department, $22 \%$ of total forest in state is fire prone due to pine trees abundance and their needles being rich in antimicrobial compounds are not degraded down easily in nature. The bioconversion can be attained by pretreating the needles with a devised chemical solution, hydrolyzing with in house depolymerising enzymes to reduce the cost of production process for commercialization and fermentation of ethanol by suitable cocultures of ethanologens. The ethanol so produced is a viable alternative in the field of bioenergy to conventional fuel. The main aim of developing this technology for biofuel production from pine needles waste is to join the global race for energy security and independency. As energy is a life line of global economy. Diminishing fossil fuel reserves, ever escalating fuel prices and increased concern over environment pollution have prompted global research community to accelerate the need to look for renewable and environmentally sustainable energy processes and this bioconversion process can be a boon to state as well as nation if being transferred to the technology starved industry.

\section{Introduction}

Energy availability, supply and use play a central role in the way societies organize themselves, from individual welfare to social and industrial development. By extension, energy accessibility and cost is a determining factor for the economical, political and social interrelations among nations. Considering energy sources, human society has dramatically increased the use of fossil fuels in the past 50 years in a way that the most successful economies are large consumers of oil. Currently, the world consumes 88 millions of barrels of oil per day (accounting for $33 \%$ of the world's energy consumption), with Canada using roughly 2 thousand barrels per day (BP Statistical Review, 2012).

Bio- ethanol is a fuel derived from renewable sources of feedstock typically plants. Because it is derived from plants, it has improved the problem of global warming to some extent because the plants used as feedstock take $\mathrm{CO}_{2}$ 
from the atmosphere as they grown. This means that almost all the $\mathrm{CO}_{2}$ produced by burning the fuel is balanced by $\mathrm{CO}_{2}$ taken from the air in the first place. The reduced $\mathrm{CO}_{2}$ emissions mean that bioethanol is good for the environment. In addition it also provide less waste and harmful emissions during production, less pollution to water, air and land, production of useful by-products and biodegradable fuel. Production of ethanol from biomass is one of the ways to minimize both environmental pollution and the consumption of crude oil, Silverstein et al., (2007).

Geopolitical factors related to security of oil supply, high oil prices and serious environmental concerns, prompted by global warming - the use of petrol for transportation accounts for one-third of greenhouse gas emissions (Wyman, 1996) - have led to a push towards decreased consumption. Indeed, the world's strongest economies are deeply committed to the development of technologies aiming at the use of renewable sources of energy. Within this agenda, the substitution of liquid fuel gasoline by renewable ethanol is of foremost importance. Ethanol has already been introduced on a large scale in Brazil, the US and some European countries, it is one of the dominating renewable biofuels in the transport sector within the coming 20 years (Table 3). Ethanol can be blended with petrol or used as neat alcohol in dedicated engines, taking advantage of the higher octane number and higher heat of vaporization; In addition, it is an excellent fuel for future advanced flexifuel hybrid vehicles. Currently, ethanol for the fuel market is produced from sugar (Brazil) or starch (USA) at competitive prices. However, this raw material base, which also has to be used for animal feed and human needs, will not be sufficient to meet the increasing demand for fuel ethanol; and the reduction of greenhouse gases resulting from use of sugar or starch-based ethanol is not as high as desirable (Farrell; 2006). Both these factors call for the exploitation of lignocellulose feedstocks, such as agricultural and forest residues as well as dedicated crops, for the production of ethanol. Woody biomass is rich in lignocellulosic material. Forests cover about $9.5 \%$ of the Earth's surface (Soccol et al., 2011), and thus, using woody biomass to make biofuel is a favourable option for replacement of conventional petroleum-based liquid fuel, because of the mass of biomass available. A US feasibility study aimed at replacing at least $30 \%$ of the petroleum usage by biomass-based fuel was conducted by Perlack et al., and they found that forest and agricultural resources provide 1.4 billion tons (dry) per year, where only roughly 1 billion tons is required to reach the replacement goal (Perlack et al., 2005).

Softwoods are gymnosperms usually known as evergreens. They are most prominent in the northern hemisphere, at $92 \%$ of all softwood forest, and have been the main source for timber (Wang and Keshwani 2010). Softwood has historically provided cellulose used in pulp and paper because of its longer fibre length.

The low xylose and other pentose content is advantageous because more aggressive processing conditions can be used to remove the lignin without having to compromise for toxic inhibitor production. This feedstock also has the potential to produce mainly monomeric hexose sugars, which are much easier to ferment than pentose sugars.

\section{Components of lignocelluloses biomass}

\section{Cellulose}

It is the most common form of carbon in biomass, accounting for $40 \%-60 \%$ by weight depending on the type of biomass (Ye sun et al., 2002). Cellulose $\left(\mathrm{C}_{6} \mathrm{H}_{10} \mathrm{O}_{5}\right)_{\mathrm{n}}$ is a polysaccharide consisting of a linear chain of several hundred to over ten thousand linked 
D-glucose units. It is the structural component of the primary cell wall of green plants, many forms of algae and the oomycetes. Its crystalline structure makes it resistant to hydrolysis. The cellulose molecules are organized in elementary fibrils with a diameter of 2-4 nm. Highly crystalline macromolecular structures of microfibrils are due to hydrogen and van der Waals bonds (Fig. 1, 2 and 3).

\section{Hemicellullose}

It is a complex polysaccharide made of heteropolymers of pentoses and hexoses carbon sugars. Hemicellulose has a random, amorphous structure with little strength, as such it is easily hydrolyzed by dilute acid or hemicellulase enzymes. Hemicelluloses differ in three ways from cellulose; by presence of shorter chain, branching of the main molecule and composition of several sugar units.

\section{Lignin}

It is one of the most abundant and important polymeric organic substance in the plant. Lignin is unusual because of its heterogeneity and lack of a defined primary structure. Lignin is a highly complex, three-dimensional polymer of different phenyl propane units, which are bound together by ether and carbon-carbon bonds. Few lignin structures have been known, but generally their structures remain unknown. Although there are great numbers of microorganisms, which are able to utilize hemicelluloses and cellulose, relatively few strains have the ability to decompose the lignin effectively Laser et al., (2002) (Table 1).

\section{Overview of the conversion process}

Ethanol is currently produced from sugar cane and starch-containing materials, where the conversion of starch to ethanol includes a liquefaction step (to make the starch soluble) and a hydrolysis step (to produce glucose). The resulting glucose is then readily fermented. Although there are similarities between the lignocellulosic and the starch process, the techno-economic challenges facing the former are large. There are several options for a lignocellulose-to-ethanol process but, regardless of which is chosen, the following features must be assessed in comparison with established sugar- or starchbased ethanol production.

Efficient de-polymerization of cellulose and hemicelluloses to soluble sugars.

Efficient fermentation of a mixed-sugar hydrolysate containing six-carbon (hexoses) and five-carbon (pentoses) sugars as well as fermentation inhibitory compounds.

Advanced process integration to minimize process energy demand.

Cost-efficient use of lignin.

The first step in the conversion of biomass to ethanol is size reduction and pretreatment. (Fig. 4) will be discussed because it is considered to be the most promising technology (Ogier et al., 1999, Yu 2004, Sheehan, 2001). The hemicellulose and cellulose polymers are hydrolyzed with enzymes or acids to release monomeric sugars (Table 2). The sugars from the pretreatment and enzymatic hydrolysis steps are fermented by bacteria, yeast or filamentous fungi, although the enzymatic hydrolysis and fermentation can also be performed in a combined step - a so-called simultaneous saccharification and fermentation (SSF). After final purification (by distillation and molecular sieves or other separation techniques), the ethanol is ready to be used as a fuel, either neat or blended with petrol. A part of the lignin, the principal solid part of the biomass remaining, can be burnt to provide heat and electricity for the process, whereas the rest is retained as a valuable 
coproduct. The most probable use today would be as an ash-free solid fuel, but various technologies are under development to convert it to a higher-value product, which could form the basis for a new branch of industrial chemistry (Fernado et al., 2006).

\section{Pretreatment}

The main objective for pretreatment is to increase the reactivity of biomass fibres, specifically to the enzymes used during hydrolysis. Figure 5 showed the changes in the structure of biomass components when subjected to pretreatment. Pretreatment can be classified into two categories: chemical and physical.

Chemical pretreatment is typically more effective, but it may result in expensive downstream clean-up. Physical pretreatment does not usually produce by-products, but it is more energy intensive. It is often necessary to use a combination of the two (physicochemical methods) to maximize the pretreatment effectiveness. Key parameters that affect the pretreatment include temperature, pressure, particle size of substrate, and the presence of catalysts (including catalyst concentration). Temperature affects the degree of lignin removal in two ways; it impacts the structure of lignin, depending on the glass transition point which is varies between types of lignin, and it affects the kinetics of the delignification process. In addition, high temperature generally favours the dissolution of hemicellulose but can also result in degradation of these sugars, which is detrimental to enzymatic hydrolysis and fermentation. Pressure affects the phase in which the pretreatment occurs; liquid phase will require higher pressure, commensurate with the required temperature for the same performance in terms of delignification, hemicellulose removal, and cellulose activation. Lastly, the addition of catalysts allows the pretreatment to be carried out at lower temperatures; this is beneficial because it may lessen the degree of generation of degradation products.

The main factors for an effective pretreatment process include sugar recovery yield, chip size required, and low energy use; ultimately, a good pretreatment will allow optimum enzymatic hydrolysis yield and will not adversely affect downstream fermentation (Yang and Wyman, 2008).

\section{Fermentation}

Microbiologically fermentation is defined as the process that leads to the production of product by mass cultivation of microorganisms. Fermentation begins as the growing population of microorganisms produces enzymes to break two-molecule sugars into single molecule sugars (if needed or capable), and then convert the single molecule sugars into the commercial chemicals and byproducts. The process uses mainly yeast to break down sugar molecules into carbon dioxide gas and ethanol (ethyl alcohol). Yields of chemicals approach a limit as the microorganisms either consume all the fermentable sugars or the products and byproducts of fermentation inhibit (or kill off) the organism.

\section{Separate Hydrolysis and Fermentation (SHF)}

Separate hydrolysis and fermentation is a process in which fermenting biomass hydrolyzates involves series of steps where the hydrolysis of cellulose and the fermentation are carried out in different units.

Main advantage is the ability to carry out both the hydrolysis and the fermentation under optimal conditions, e.g. enzymatic hydrolysis at $40-50^{\circ} \mathrm{C}$. Varga (2003). Each step can be performed at its optimal operating conditions. 
Reaction time, temperature, $\mathrm{pH}$, enzyme dosage and substrate load are the most important factor to be consider during the saccharification Oscar et al., (2007). Productivity and yields reported so far are lower SHF as compared other and fermentation processes (Wingren, 2003). The major disadvantage is that the released sugars inhibit the cellulases. So this method is strongly affected by end-product inhibition Alfani et al., (2000) (Fig. 6).

\section{Simultaneous saccharification and fermentation (SSF)}

The simultaneous hydrolysis and fermentation process entails inoculating the enzymeproducing microorganism (enzyme) and the ethanol producing microorganisms at the same time so that the produced sugars are simultaneously converted to ethanol. Because the produced sugars are immediately converted to ethanol, the problem of feedback inhibition is avoided. Contamination risk is also low since the sugar concentration is very low throughout the process.

Furthermore, less enzyme is needed because glucose inhibition is avoided. In the simultaneous hydrolysis and fermentation processes, however, recycling of the biocatalysts is very difficult when free cells or free enzymes are (Wingren; 2003). This problem can be avoided by immobilizing the biocatalysts.

Another problem is that the optimal conditions for hydrolysis are different from those for fermentation. The temperature optima for most hydrolysis enzymes are often much higher than those for most fermenting microorganisms. The use of thermophilic or thermotolerant strains of fermentation microorganisms can help to overcome this problem (Moriera et al., 2006).
Simultaneous Saccharification and CoFermentation (SSCF)

The inclusion of the pentose fermentation in the SSF, process is called simultaneous saccharification and cofermentation (SSCF). This process represents the hydrolysis and cofermentation of pentose and hexose sugars in one vessel. In this process, it is important that both fermenting microorganisms be compatible in terms of operating $\mathrm{pH}$ and temperature. Olsson et al., (1993) reported that the co-culture of $P$. stipitis and Brettanomyces clausennii has been utilized for the SSCF of aspen at $380 \mathrm{C}$ and $\mathrm{pH}$ of 4.8 yielding $369 \mathrm{~L} \mathrm{EtOH}$ per ton of aspen during $48 \mathrm{~h}$ batch process. Chandrakant et al., (1998) suggest that a combination of Shehatae and S. cerevisiae is suitable for this kind of process. Progress is rapid in the field of xylose fermentation; a few industrial modified yeast strains have yet shown the demonstrated capability of fermenting xylose in lignocellulosic hydrolysates efficiently. Arabinose fermentation in SSF has not yet been reported, although arabinose fermenting S.cerevisae strains have recently been constructed. Co-utilizating arabinose and xylose strains of $Z$. mobilis have been developed [Hahn-Haegdral 1991; Olofsson K; 2008). Other than conventional yeast, Zymomonas mobilis has emerged as promising microorganisms for ethanol production. This organism has several advantages and it is suitable for continuous fermentation (Gunasekaran, 1990; Rogers, 1979) over Saccharomyces cerevisiae (Saigal et al., 1993) (Fig. 7)

\section{Use of recombinants for improved ethanol yield}

A modified genome shuffling method was developed to improve xylose fermentation by $S$. cerevisiae. Recombinant yeast strains were constructed by recursive DNA shuffling with 
the recombination of entire genome of $P$. stipitis with that of S. Cerevisiae (Zhang and Geng, 2012).

The robustness under heat, acetic acid, and furfural stresses was improved for ethanologenic $S$. cerevisiae using genome shuffling. Recombinant yeast strain R32 could grow at $45^{\circ} \mathrm{C}$, and resist $0.55 \%(\mathrm{v} / \mathrm{v})$ acetic acid and $0.3 \%(\mathrm{v} / \mathrm{v})$ furfural at $40^{\circ} \mathrm{C}$. When ethanol fermentation was conducted at temperatures ranging from 30 to $42^{\circ} \mathrm{C}$, recombinant strain R32 always gave high ethanol production. After $42 \mathrm{~h}$ of fermentation at $42^{\circ} \mathrm{C}, 187.6 \pm 1.4 \mathrm{~g} / \mathrm{l}$ glucose was utilized by recombinant strain R32 to produce $81.4 \pm$ $2.7 \mathrm{~g} / 1$ ethanol, which were respectively 3.4 and 4.1 times those of CE25. After $36 \mathrm{~h}$ of fermentation at $40^{\circ} \mathrm{C}$ with $0.5 \%(\mathrm{v} / \mathrm{v})$ acetic acid, $194.4 \pm 1.2 \mathrm{~g} / \mathrm{l}$ glucose in the medium was utilized by recombinant strain R32 to produce $84.2 \pm 4.6 \mathrm{~g} / \mathrm{l}$ of ethanol. The extent of glucose utilization and ethanol concentration of recombinant strain R32 were 6.3 and 7.9 times those of strain CE25. The ethanol concentration produced by recombinant strain $\mathrm{R} 32$ was 8.9 times that of strain CE25 after fermentation for $48 \mathrm{~h}$ under $0.2 \%(\mathrm{v} / \mathrm{v})$ furfural stress at $40^{\circ} \mathrm{C}(\mathrm{Lu}$ et al., 2011).

The T7-expression system has been very useful for protein expression in Escherichia coli. A T7- expression transposon was constructed, which allowed simple construction of T7-expression Zymomonas mobilis. This transposon contained the $\mathrm{T} 7$ RNA polymerase being driven by the gap promoter from Z. mobilis. The T7-expression fadK genomes were introduced into $Z$. mobilis ATCC 31821 in order to increase ethanol production. The recombinant bacteria were named as Z.M.F-1, Z.M.F-2, Z.M.F-3, and Z.M.F-4. However, Z.M.F-4 had the highest ability of producing ethanol by selection. Compared with Z. mobilis ATCC 3182, there was $7 \%$ increase in ethanol production for Z.M.F-4 with corn hydrolysates as fermentation medium. The 16 mmolL-1 supplement of calcium chloride could significantly improve the ethanol production. This was also clearly demonstrated by a variety of kinetic parameter values over time in Z.M.F-4 under high sugar osmotic stress. Calcium chloride not only increased the fermentation ability but also improved the stability of cell membrane (Zeng et al., 2010).

\section{Economics}

To be competitive, and find acceptance of ethanol bioconversion process at commercial scale, the cost for the bioconversion of biomass to liquid fuel must be lower than different gasoline prices (Subramaniyan, 2000). The cost of feedstock and cellulolytic enzymes are two important parameters for low cost of ethanol production. Biomass feedstock represents around $40 \%$ ethanol production cost (Chandel et al., 2007). Estimated cost of ethanol production from various feedstocks varies widely between different investigations, with production costs in the range US\$ 0.32-1.0/1 ethanol (Nystrom et al., 1985; Lynd et al., 1996; von Sivers and Zacchi, 1996). The lower costs are usually obtained for rather large plant capacities above 600,000 metric tons of dry raw material per year. Most cost analyses are performed for hardwoods although some are for softwoods (Kadam et al., 2000). The cost of raw material is a major contributor (about 25$40 \%$ ) to the total production cost, although it varies between different studies due to differences in the local price of raw material (US\$ 22-61/metric ton dry matter). Most cost estimations are based on lab-scale and, to some extent, pilot-scale data for individual process steps and should be treated with caution and not used to obtain an absolute production cost. 
Table.1 Composition of pine

\begin{tabular}{|l|c|c|}
\hline Component & \% Dry basis & \% Wet basis \\
\hline Glucan & $\mathbf{4 2 . 7 0}$ & $\mathbf{2 1 . 7 0}$ \\
\hline Xylan & $\mathbf{6 . 0 0}$ & $\mathbf{3 . 0}$ \\
\hline Galactan & 2.50 & $\mathbf{1 . 3 0}$ \\
\hline Arabinan & $\mathbf{1 . 1 0}$ & $\mathbf{0 . 6 0}$ \\
\hline Mannan & $\mathbf{1 2 . 9 0}$ & $\mathbf{6 . 5 0}$ \\
\hline Others & $\mathbf{0 . 4 0}$ & $\mathbf{0 . 2 0}$ \\
\hline Lignin & $\mathbf{3 1 . 2 0}$ & $\mathbf{1 5 . 6 0}$ \\
\hline Ash & $\mathbf{0 . 4 0}$ & $\mathbf{0 . 2 0}$ \\
\hline Proteins & $\mathbf{0 . 4 0}$ & $\mathbf{0 . 2 0}$ \\
\hline Extractives & $\mathbf{2 . 4}$ & $\mathbf{1 . 2 0}$ \\
\hline Moisture & $\mathrm{NA}$ & $\mathbf{5 0 . 0 0}$ \\
\hline
\end{tabular}

Table.2 Different softwood as a biofuel feed stock

\begin{tabular}{|c|c|c|}
\hline Type of Pretreatment & Optimum Conditions & Results \\
\hline Catalyzed Autohydrolysis & $215^{\circ} \mathrm{C}, 3 \mathrm{~min}$ & $\begin{array}{l}\text { Spruce - Enzymatic Hydrolysis } \\
\text { Yield - } 70 \% \quad(2 \% \text { solids } \\
\text { loading20FPU cellulase per gram } \\
\text { of cellulose, } 72 \mathrm{hr})\end{array}$ \\
\hline Liquid Hot Water & $200^{\circ} \mathrm{C}-230^{\circ} \mathrm{C}, 15 \mathrm{~min}$ & $\begin{array}{l}\text { Sugar Extraction: } \\
4 \%-22 \% \text { Cellulose } \\
\text { Over } 90 \% \text { Hemicellulose }\end{array}$ \\
\hline $\begin{array}{lll}\text { Sulfite Pretreatment } & \text { to } \\
\text { Overcome Recalcitrance } & \text { of } \\
\text { Lignocellulose (SPORL) } & \end{array}$ & $\begin{array}{l}160^{\circ} \mathrm{C}-190^{\circ} \mathrm{C}, 10 \mathrm{~min} \\
30 \mathrm{~min}\end{array}$ & $\begin{array}{l}\text { Enzymatic Hydrolysis Yield - } \\
98 \%(2 \% \text { solids loading, 20FPU } \\
\text { cellulase and 30CBU } \beta- \\
\text { glucosidase per gram of cellulose, } \\
48 \mathrm{hr})\end{array}$ \\
\hline Ammonia (AFEX) & $160^{\circ} \mathrm{C}-180^{\circ} \mathrm{C}, 14 \mathrm{~min}$, & $\begin{array}{l}\text { Enzymatic Hydrolysis Yield - } \\
50 \%(2 \% \text { solids loading, low } \\
\text { enzyme loading }-10 \mathrm{FPU} / \mathrm{g} \\
\text { cellulose) } \\
\text { Considered to be less efficient in } \\
\text { pretreating softwood than } \\
\text { hardwood }\end{array}$ \\
\hline Organosolv, with acid catalyst & $200^{\circ} \mathrm{C}$ & $\begin{array}{l}\text { Enzymatic Hydrolysis Yield - } \\
90 \% \\
(2 \% \text { solids loading, 20FPU } \\
\text { cellulase and } 30 \mathrm{CBU} \quad \beta- \\
\text { glucosidase per gram of cellulose, } \\
48 \mathrm{hr})\end{array}$ \\
\hline
\end{tabular}

Source: (Mosier et al., 2005; Galbe and Zacchi 2007; Zhu and Pan 2010) 
Table.3 Voluntary and mandatory biofuel targets of some countries

\begin{tabular}{|c|c|c|}
\hline Country & Target & Condition \\
\hline Germany & $\begin{array}{l}\text { Addition of } 6.75 \% \text { of anhydrous ethanol to gasoline in } 2010 \text {; } \\
\text { increase to } 8 \% \text { in } 2015 \text { and } 10 \% \text { in } 2020 \text {. }\end{array}$ & Mandatory \\
\hline Brazil & $\begin{array}{l}\text { Mixture of } 20 \% \text { to } 25 \% \text { of anhydrous ethanol in gasoline and } \\
5 \% \text { of biodiesel in diesel in } 2010 \text {; expansion of the use of } \\
\text { hydrated ethanol. }\end{array}$ & Mandatory \\
\hline Canada & $\begin{array}{l}\text { Addition of } 5 \% \text { of anhydrous ethanol in gasoline in } 2010 \text {; } \\
\text { addition of } 2 \% \text { of biodiesel in diesel in } 2012 \text {. }\end{array}$ & Mandatory \\
\hline China & Utilization of $15 \%$ of biofuels in the transport sector. & Voluntary \\
\hline France & $\begin{array}{l}\text { Addition of } 7 \% \text { of anhydrous ethanol in gasoline in } 2010 \mathrm{a} \text { and } \\
\text { increase to } 10 \% \text { in } 2015 \mathrm{~b} \text {. }\end{array}$ & Voluntary and bmandatory \\
\hline Italy & $\begin{array}{l}\text { Addition of } 5.75 \% \text { of anhydrous ethanol in gasoline in } 2010 \text { and } \\
\text { increase to } 10 \% \text { in } 2010 .\end{array}$ & Mandatory \\
\hline $\begin{array}{l}\text { European } \\
\text { Union }\end{array}$ & Utilization of $10 \%$ of biofuels in 2010 & Mandatory \\
\hline $\begin{array}{l}\text { United } \\
\text { Kingdom }\end{array}$ & Utilization of $5 \%$ of biofuels in 2010. & Mandatory \\
\hline
\end{tabular}

Source: FAO 2008

Fig.1 Composition of dry pine by mass (w/w\%) (Galbe and Zacchi, 2007)

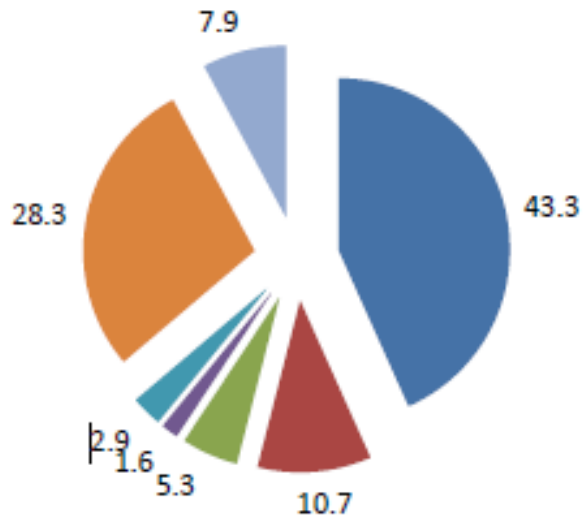

Glucose
Mannose
Xylose
Arabinose
Galactose
Lignin
Other

Fig.2 Cellulose Chain (Adapted from Gardner and Blackwell 1974)

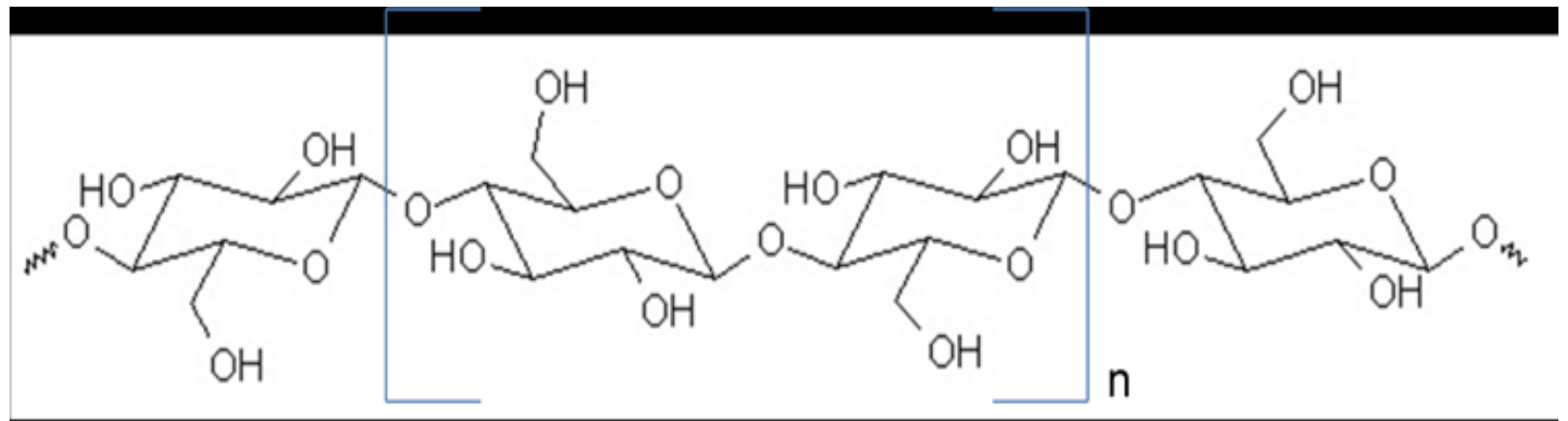


Fig.3 Lignocellulosic Biomass Structure and Component (Adapted from Rubin, 2008)

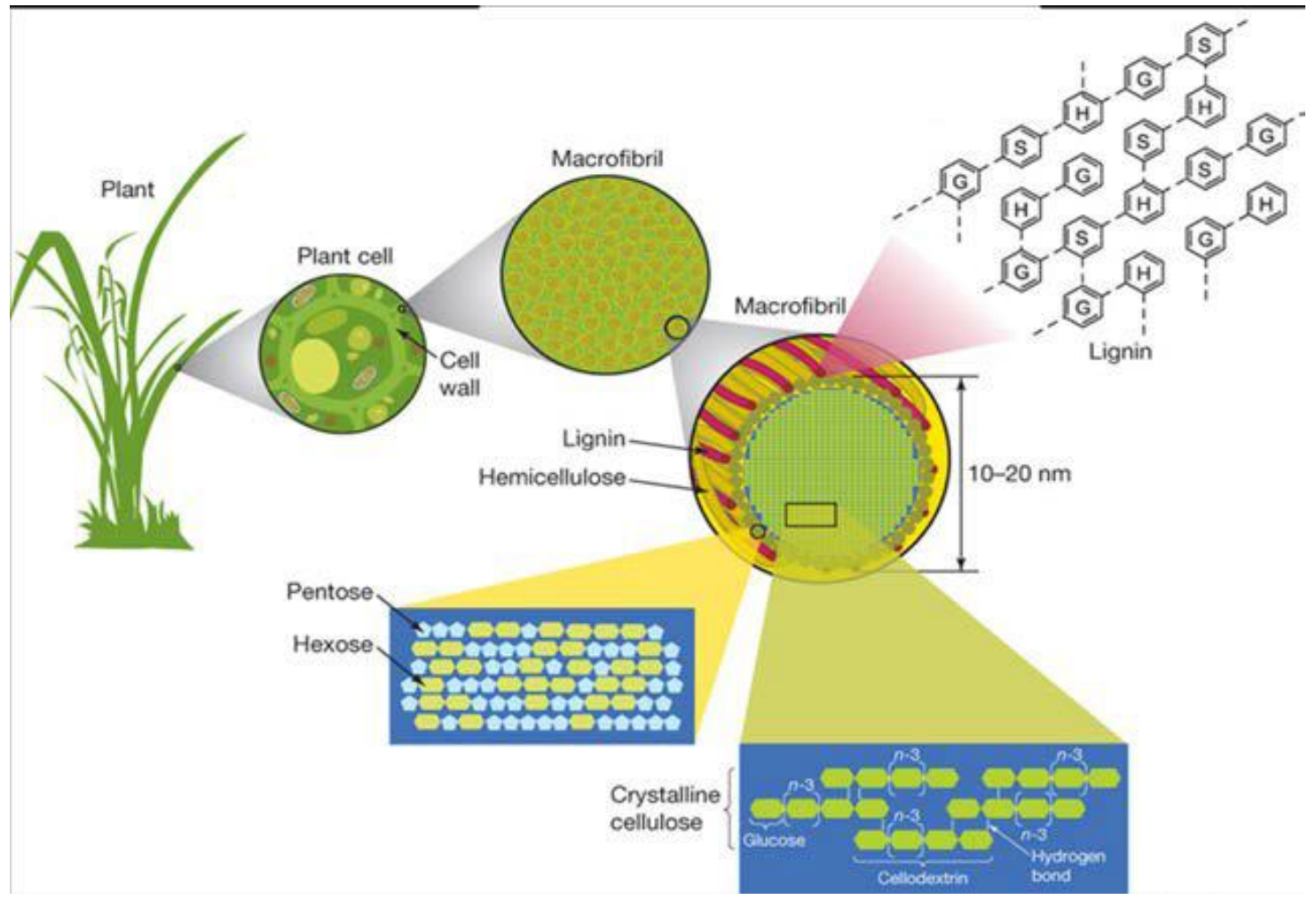

Fig.4 Schematic flowsheet for the conversion of biomass to ethanol

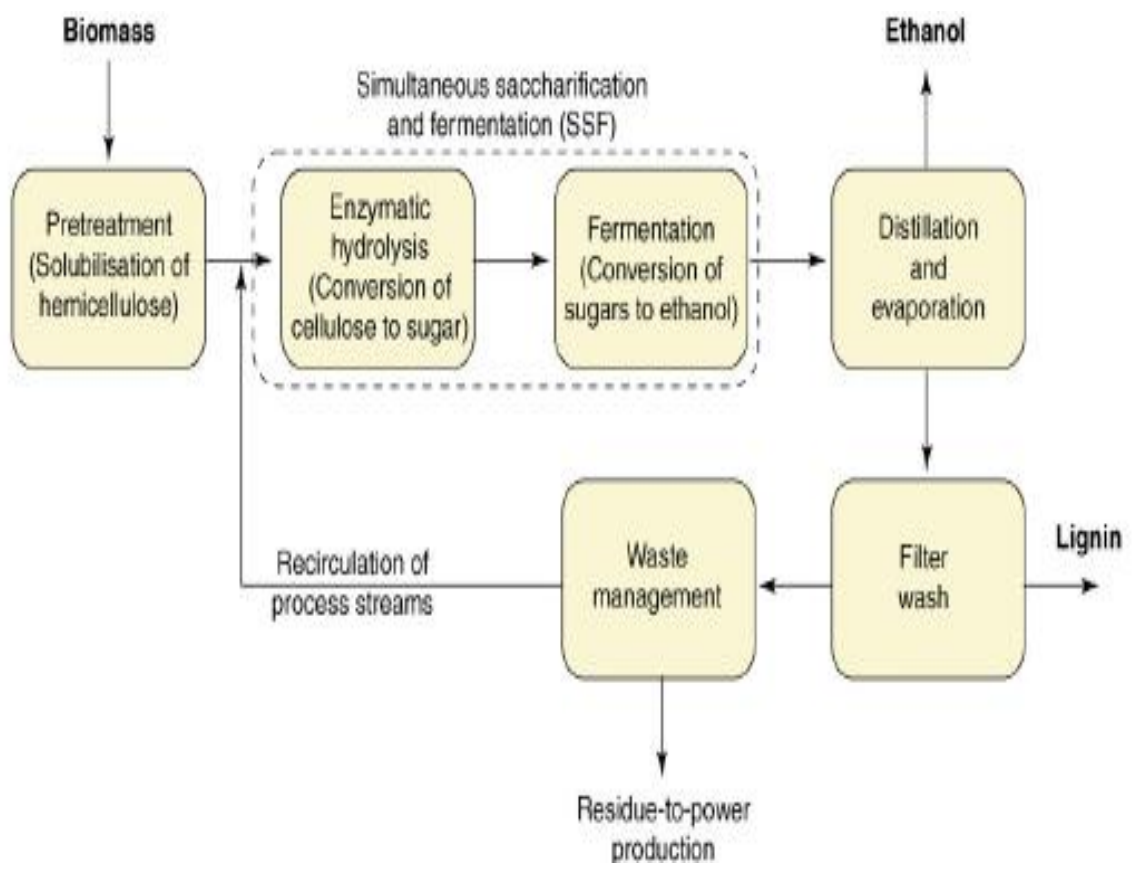


Fig.5 Schematic representation of effect of pretreatment on biomass (Mosier et al., 2005)

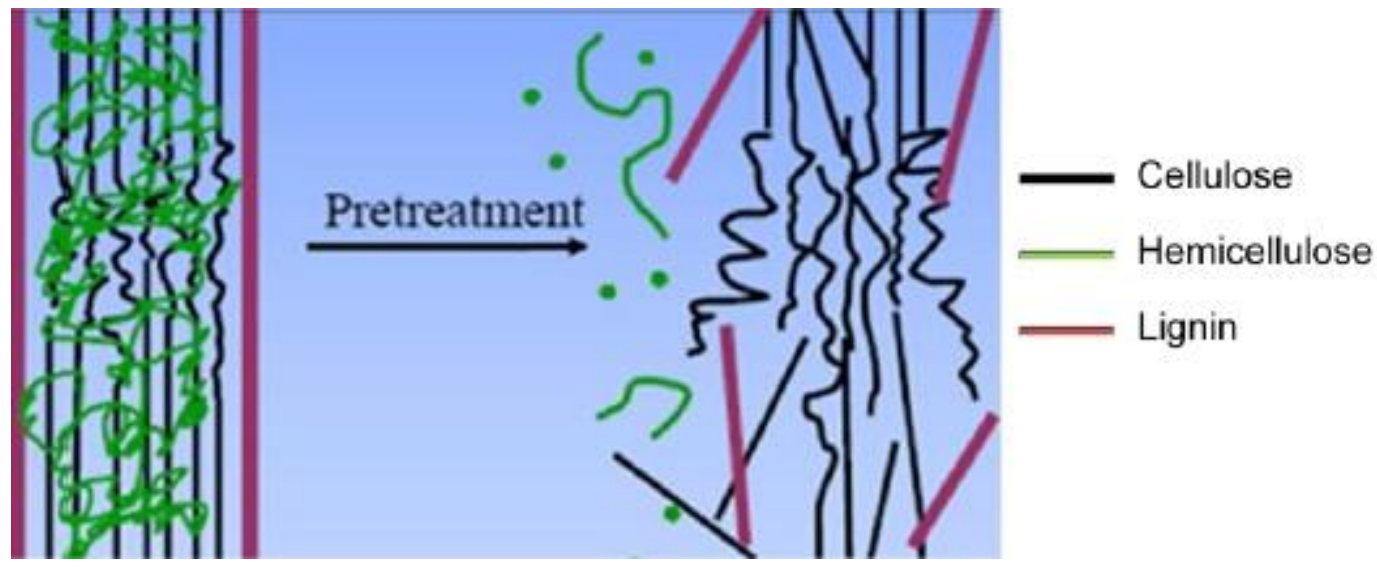

Fig.6 Separate C5 and C6 sugar fermentation SSF and SSCF

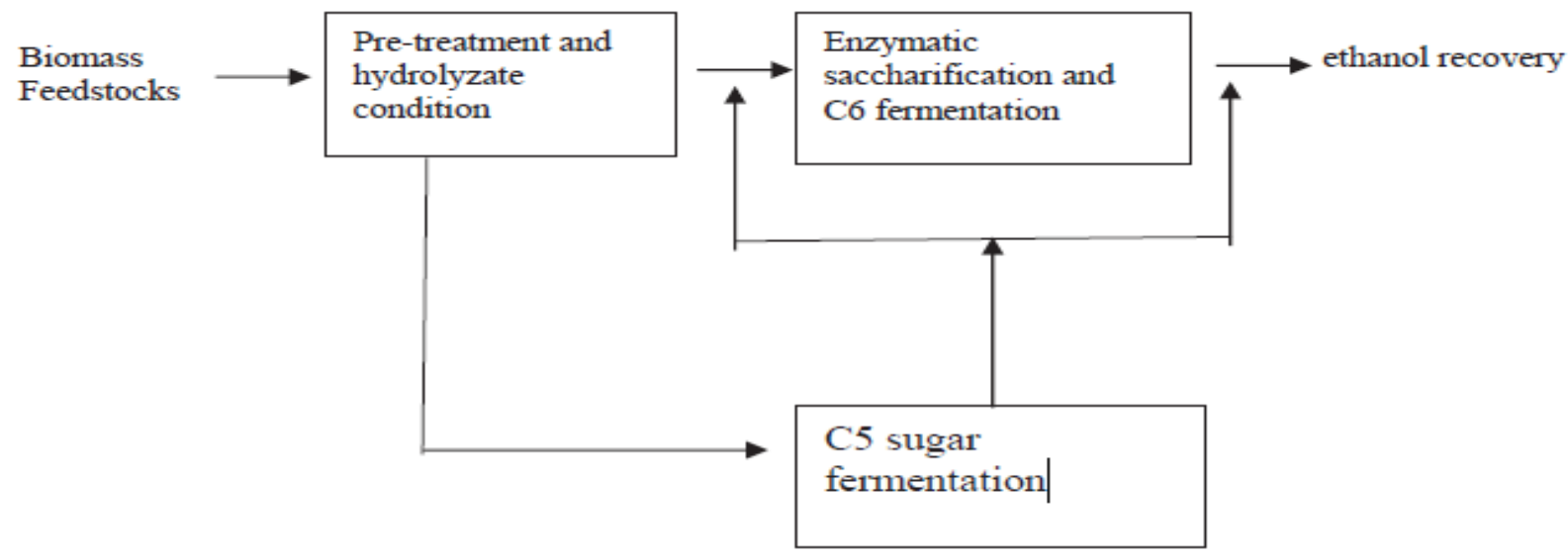

Fig.7 SSF with combined C5 and C6 sugar co-fermentation SSCF

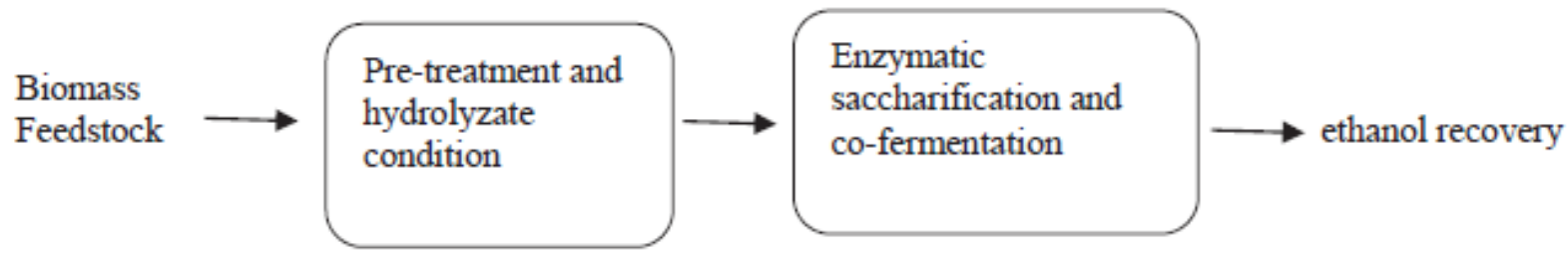

In conclusion, the environmental changes influenced by greenhouse gas emissions and global warming, the rising prices of crude oil and its derivatives, and the ever growing global demand for fuels, have led to the development of numerous biotechnological processes to minimize the use of fossil fuels in the late 20 th and early 21 st centuries. These innovations include the development of biofuels, such as ethanol, which started in Brazil in 1920 and was strongly boosted by Brazil's Pro-Alcohol Program established in 1975. Since then, ethanol participates effectively in Brazil's energy matrix and is one of the cleanest technologies in the world. Population growth, an expanding agribusiness 
sector and the search for sustain- able development has resulted in the eco-efficient production of cellulosic ethanol from low-cost agro-industrial residues and municipal waste of plant origin.

\section{References}

Alfani F. et al., (2000). Comparison of SHF and SSF processes for the bioconversion of steam-exploded wheat straw, J. of Industrial Microbiology and Biotechnology.

Chandel A K, Chan E S, Rudravaram R, Narasu M L \& Rao V R, Economics and environmental impact of bioethanol production technologies: an appraisal, Biotechnology and Molecular Biology Review, 2007; 2(1): 014-032

Chandrakant, P., Bisaria, V.S., 1998. Simultaneous bioconversion of cellulose and hemicellulose to ethanol. Critical Reviews in Biotechnology 18 (4), 295-331.

Coughlan, M.P., Ljungdahl, L.G., (1988). Comparative biochemistry of fungal and bacterial cellulolytic enzyme system. In: Aubert, J.-P., Beguin, P., Millet, J. (Eds.), Biochemistry and Genetics of Cellulose Degradation, pp. 11-30.

Dadi, A.O., Varanasi, S., Schall, C.A., 2006. Enhancement of Cellulose Saccharification Kinetics Using an Ionic Liquid Pretreatment Step. Biotechnology and Bioengineering 95(5), 904-910.

Farrell et al., (2006) Ethanol can contribute to energy and environmental goals. Science 311, 506-508

Fernando, S. et al., (2006) Biorefineries: current status, challenges, and future direction. Energy Fuels 20, 17271737
Food and Agriculture Organization, "El Estado Mundial de la Agricultura y la Alimentación: Biocombustibles: Perspectivas, Riesgos y Oportunidades," FAO, Roma, 2008.

Galbe, M., Zacchi, G., 2007. Pretreatment of Lignocellulosic Materials for Efficient Bioethanol Production. Adv Biochem Engin/Biotechnol 108, 41-65

Gardner, K.H., Blackwell, J., 1974. The structure of native cellulose. Biopolymers 13(10), 1975-2001

Gunasekaran P, Krunakaran T, Kamini N R \& Mukundan A G, Current status and prospects of an ethanol producer Zymomonas mobilis, International Journal of Microbiology,1990; 30: 107-133.

Hahn-Haegdral B, Jeppsson H, Olsson L \& Mohagheghi A, An interlaboratory comparison of the performance of ethanol producing microorganisms in a xylose rich acid hydrolysate, Applied Microbiology and Biotechnology, 1994; 41(1): 62-72.

Jing, X., Zhang, X., Bao, J., 2009. Inhibition Performance of Lignocellulose Degradation Products on Industrial Cellulase Enzymes During Cellulose Hydrolysis. Appl Biochem Biotechnol 159, 696-707

Jorgensen, H., Kutter, J.P., and Olsson, L. 2003. Separation and quantification of cellulases and hemicellulases by capillary electrophoresis." Analytical Biochemistry. 317(1): 85-93.

Kadam KL, Wooley RJ, Aden A, Nguyen QA, Ferraro FM (2000) Softwood forest thinnings as a biomass source for ethanol: a feasibility study for California. Biotechnol Prog 16:947957

Keshwani D R. 2010. Modeling changes in biomass composition during microwave based alkali preteatment of 
switchgrass. Biotechnology and Bioengineering 105(1): 88-97

Lu Y, Cheng Y F, He X P, Guo X N and Zhang B R.2011. Improvement of robustness and ethanol production of ethanologenic Saccharomyces cerevisiae under co stress of heat and inhibitors. Journal of Industrial Microbiology and Biotechnology.Doi.1007/s10295-0111008

Moriera J R, Mashima H \& Tanaka, Scale up of fuel ethanol production from sugar beet juice using loofa sponge immobilized bioreactor, Bioresource Technology, 2006;76:1-8.

Mosier N, Wyman C, Dale B, Elander R, Lee Y Y, Holtzapple $M$ and Ladisch $M$. 2005. Features of promising technologies for pretreatment of lignocellulosic biomass. Bioresource Technology 96: 673-686

Ogier, J.C. et al., (1999) Ethanol production from lignocellulosic biomass. Oil Gas Sci Technol 54, 67-94

Olofsson K, Bertilsson M \& Liden G, A short review on ssf- an interesting process option for ethanol production from lignocellulosic feedstocks, Biotechnology Biofuels, 2008; 1:7.

Olsson L, Hahn-Hägerdal B: Fermentative performance of bacteria and yeasts in lignocellulose hydrolysates. Process Biochem 1993, 28(4):249-257.

Palmqvist, E., Hahn-Hägerdal, B., 2000. Fermentation of lignocellulosic hydrolysates. II: inhibitors and mechanisms of inhibition. Bioresource Techology 72, 25-33

Perlack, R.D., Wright, L.L., Turhollow, A.F., Graham, R.L., Stokes, B.J., Erbach, D.C., 2005. Biomass as Feedstock for a Bioenergy and Bioproducts Industry: The Technical Feasibility of a BillionTon Annual Supply. U.S. Department of

Energy (http://feedstockreview.ornl.gov/pdf/bi llion_ton_vision.pdf)

Rabinovich, M L, Melnik M S and Boloboba AV. 2002. Microbial cellulases ( Review)," Appl. Biochem. Microbiol. 38(4), 305-321.

Rogers P L, Lee K J \& Tribe D E, Kinetics of alcohol production by Zymomonas mobils at higher sugar concentration, Biotechnology Letters,1979; 1(4):165170.

Rubin, E.M., 2008. Genomics of cellulosic biofuels. Nature 454, 841-845.

Saigal D, Yeast strain development for ethanol production, Indian Journal of Microbiology, 1993; 33:159-168.

Sheehan, J. (2001) The road to bioethanol. A strategic perspective of the US Department of Energy's National Ethanol Program. In Glycosyl Hydrolases for Biomass Conversion (Himmel, M.E., Baker, J.O. and Saddler, J.N., eds), pp. 2-25, American Chemical Society

Silverstein, R.A. et al.,(2007) comparison of chemical pretreatment methods for improving saccharification of cotton stalks. Bioresource Technol. 2007, 98, 3000-3011.

Soccol, C.R., Faraco, V., Karp, S., Vandenberghe, L.P.S., Thmaz-Soccol, V., Woiciechowski, A., Pandey, A., 2007. Lignocellulosic Bioethanol: Current Status and Future Perspectives.. Biofuels - Alternative Feedstocks and Conversion Processes, 101-122

Stenberg K. et al., (2000). The influence of lactic acid formation on the simultaneous saccharification and fermentation (SSF) of softwood to ethanol. Enzyme Microb. Technol. 26:71-79

Subramaniyan S \& Prema P, Cellulose tree xylanase from Bacillus and other 
microorganisms, FEMS Microbiology Letters, 2000;183: 1-7.

Sun Y, and Cheng J. 2002. Hydrolysis of lignocellulosic materials for ethanol production. A review," Bioresource Technol. 83(1), 1-11.

Taherzadeh M J and Karimi K. 2008. Pretreatment of Lignocellulosic Wastes to Improve Ethanol and Biogas Production: A Review. International Journal of Molecular Sciences 9: 1621-1651.

Tengborg, C., Galbe, M., Zacchi, G., 2001. Reduced inhibition of enzymatic hydrolysis of steam-pretreated softwood. Enzyme and Microbial Technology 28, 835-844.

The Role of Agricultural Biotechnologies for Production of Bioenergy in Developing Countries", an FAO seminar held in Rome on 12 October 2007, http://www.fao.org/biotech/seminaroct 2007.htm

Tomás-Pejó, E., Alvira, P., Ballesteros, M., Negro, M.J., 2011. Chapter 7Pretreatment Technologies for Lignocellulose-to-Bioethanol Conversion. Biofuels - Alternative Feedstocks and Conversion Processes, 149-176
Wingren A, Galvem \& Zacchi G, Evaluation of producing ethanol from softwood and comparison of SSF and SHF, Bioethanol Progress.2003; 19:11091117.

Wyman, CE. (1996). Ethanol production from lignocellulosic biomass: Overview. In Handbook on Bioethanol, Production and Utilization (Wyman, C.E., ed.), pp.1-18, Taylor \& Francis.

Yang, B., Wyman, C.E., 2008. Pretreatment: the key to unlocking low-cost cellulosic ethanol. Biofuels Biop. Biorefining 2, 26-40

$\mathrm{Yu}$, Z. and Zhang, H.X. (2004) Ethanol fermentation of acid-hydrolyzed cellulosic pyrolysate with Saccharomyces cerevisiae. Bioresour. Technol. 93, 199-204

Zhang W and Geng A. 2012. Improved ethanol production by a xylose fermenting recombinant yeast strain constructed through a modified genome shuffling method. Biotechnology for Biofuels 5(46):1-11

Zhao, X., Cheng, K., Liu, D., 2009. Organosolv pretreatment of lignocellulosic biomass for enzymatic hydrolysis. Appl Microbiol Biotechnol 82, 815-827

\section{How to cite this article:}

Divya Tandon and Nivedita Sharma. 2019. Ethanol from Softwood Biomass: Review Article. Int.J.Curr.Microbiol.App.Sci. 8(02): 2915-2927. doi: https://doi.org/10.20546/ijcmas.2019.802.340 